\title{
The Basic Concept of Narratology and Narrative
}

\author{
Devi Sari Panggabean \\ Universitas Sumatera Utara, Indonesia \\ Email: devisaripgb@gmail.com \\ Rahmadsyah Rangkuti \\ Universitas Sumatera Utara, Indonesia
}

\begin{abstract}
The field of narratology is concerned with the study and analysis of narrative texts. It puts under investigation literary pieces of language and yields an understanding of the components has in its very texture. The aim of this article is to provide insights about the field of 'narratology' and its associated subject of study 'narrative'. It also tries to sketch the main issues concerning these two concepts. For this, the present review is presented in two major sections, each with related discussions about narratology and narrative. The first major part, narratology, will be presented in three sections: the first section, deals with the definitions and origins of narratology. The definitions are insected and the researchers show how they go from general (encompassing all which is narrated) to more specific (eno mpassing literary narratives told by a narrator) ones. The second section, focuses on the two phases of n atolo gy wich are classical and post-classical ones in which narratology changed its orientations and scope The ast sec on devoted to some of the elements and components of which narratology is made up, such as narr tion liz tion narrative situation, action, story analysis, tellability, tense, time, and narrative modes which will elaborated on more details. The second major part, narrative, will be presented in four sections: first the conce fill be de ine an introduced. Then the features which make a narrative will be specified and elaborated on. In the thi d section sone of the elements of narratives like story, discourse, events, and existents are stressed. In the last sution, $j$ elu dated that narrative is not just a written printed genre, rather it consists of performed genres such as plos, fi. ns, and gras.

Keywords: Narratology, Narrative, Definitions, tassiv

INTRODUCTION

The beginings of narratology - like the roots of all Western theories of fiction - Jahn (2005) asserts, go back to Plato's (428-348 BC) and Aristotle's (384-322 BC) distinction between 'mimesis' (imitation) and 'diegesis' (narration) (Jahn, 2005, N2.1.4.). The two terms are crucial and some have used them as their basic terminology in their studies. One such writer and theorist is Chatman (1990) who uses these concepts to distinguish between diegetic narrative genres which include: epic narratives, novels, short stories and mimetic narrative genres which are: plays, films, and cartoons.

According to Phelan (2005), Tzvetan Todorov coined the French term narratologie ("narratology") in his 1969 book Grammaire du "De'came'ron". Phelan points that Todorov used this word in parallel with biology, sociology, and so forth to suggest "the science of narrative".

Aside from the beginning with which narratology is identified, one may consider what narratology exactly is and what it does. The ans-

\section{poo-class cal narratology}

we can be fou d ty what Gerard Prince (1990) asserts when le says an tology helps to show the structure whind norre tive text. In defining narratology, he st sses the to mpo al aspect of narratives believing tho har atolog illuminates temporality and also huma beinos as temporal beings. Prince also pinpoints narratology's vital implications for humans' self-understanding. Bal (1991) also sketches narratology in this way as she explains it is: "the theory of narrative text. A theory is a systematic set of generalized statements about a particular segment of reality. That segment of reality, the corpus, about which narratology attempts to make its pronouncement consists of narrative text" (p. 264). In a classification for narratology, Jahn (2005) bases his discussion on Ferdinand de Saussure's concepts of 'signifier' and 'signified'. Saussure believes a signifier to be a form and a signified to represent a kind of meaning. Following these understandings, Jahn asserts that for a narrative text, the discourse or the specific mode of presentation is the signifier and the story (which transfers a sort of meaning and content) is the signified. Thus for Jahn, story and
\end{abstract}


discourse are the backbones of his narrative investigations. Discourse, as viewed by Jahn, refers to stylistic innovations and choices that make up the ultimate realization of a narrative text which is unique to every writer. However, story refers to the actions that "emplot" and makes "a stream of events into a trajectory of themes, motives, and plot lines" (2005, N2.1.3.).

\section{NARRATOLOGY}

\section{Definition and origin of narratology}

The study of narrative, as put forward by Fludernik (2006), is narrative theory. Narrative theory, or narratology, is the study of narrative as a genre. Its objective is to describe "the constants, variables and combinations typical of narrative and to clarify how these characteristics of narrative texts connect within the framework of theoretical models (typologies)" (ibid, p. 8).

Origi ally established by Tzevan Todorov, narratolog de inet (by him) as the theory of the strua ures of nar ative in Phelan, 2006). The term narratold gy $b$ as veen dened by some writers in more or les the same $y$ ay. The general idea we get from these definit ons is ty arratology studies the formal fecu ures of narr tive. Prince (1982), for instance, define it Is: "the study of the form and functioning of na rativ (p. 7). This term is moreover defined by $\mathrm{M}$ ister (2009) as a "humanities discipline" which is de dicated to "the study of the logic,principles, and practices of narrative representation" (in Huhn, Meister, Pier, Schmid, and Schönert, 2009, p. 329). However, Schmid (2010) expresses that there is a criticism by which writers are warned that narratology must not confine itself to be merely analytic; because this will result in objective descriptions which hence will be deprived of any free interpretation. This outlook hints at the idea that narratology should make its borders larger. It suggests that narratology, with widening its scope, can be more insightful. This is reflected in the era of post-classical narratology. It gives narratology a respite to interact with other disciplines (the next section will provide a more detailed discussion on this issue).

Narratology examines what all narratives have in common, and what allows them to be narratively different (Prince, 1982). There is a delicate point in the definition of narratology to which Prince has pinpointed and that is the idea that narratology is not concerned with "the history of particular novels or tales, or with their meaning, or with their esthetic value, but rather with the traits which distinguish narrative from other signifying systems and with the modalities of these traits" (Prince, 1982, p. 5). So it is clear from this and other definitions that narratology does not deal with the abstract levels of a specific narrative nor with the interpretative dimension of narratives; but it investigates narratives' structure and basic traits which ultimately give shape to what a narrative is and what distinguishes it from other forms.

Considering the origin and roots of 'narratology' about both its name and discipline, Prince explains that though the term narratology is new, the discipline and what they do in it, is not new but it goes back at least to Plato and Aristotle (1982). But as a discipline, Jahn explains, narratology started to take form in 1966, and this was the time when the French journal Communications published a relevant issue with the title "The structural analysis of narrative" (Jahn, 2005,N2.1.1.). Jahn explains that it was just three years later that Tzevan Todorov coined the term narratology to refer to the theory of the structures of narrative and this was when a narratologist aims to describe and investigate the structural properties of a narrative. This is called "dissecting the narrative phenomenon into its component parts" and attempting to determine its functions and relationships (ibid., N2.1.1.).

Admittedly, Prince (1982) also asserts that dur ig the twentieth century narratology has be en cons derably developed. He says that narrato ogical activity $\mathrm{m}$, been growing since the last ten years signi icantly. Surther, he explains that narratolog xpanded its sy opes to other literary fields and it also att acted somany "literary analysists and linguints as we 1 as hilosophers, psychologists, psychoanalye s, biby cists, folklorists, anthropologists, and communication theorists" (p. 4) in many parts of the world.

Narratology can be considered based on two classifications introduced by Jahn. In making a distinction between discourse narratology and story narratology, Jahn (2005) refers to the Swiss linguist Ferdinand de Saussure who, in Jahn's words, is the "founding father of structuralis" (N2.1.3), and explains how he differentiated the two concepts of discourse and story, with his specific terminology which are: the signifier which is the same as discourse (a mode of presentation) and the signified which is the same as story (an action sequence). Thus, based on the same source narratology pursues two traditions: discourse narratology analyzes the stylistic choices that determine the form or realization of a narrative text (or performance, in the case of films and plays). Also of interest are the pragmatic features 
that contextualize text or performance within the social and cultural framework of a narrative act. Story narratology, by contrast, focuses on the action units that 'emplot' and arrange a stream of events into a trajectory of themes, motives and plot lines. The notion of emplotment plays a crucial role in the work of theorists like the historian Hayden White (1996 [1981]) and cultural philosophers such as Paul Ricoeur (1991) and Michel Foucault. (Jahn, 2005, N2.1.3)

\section{Classical and post-classical narratology}

Narratological studies consist of two phases: 1) the classical phase, and 2) the post classical phase. "During its initial or classical phase, from the mid-1960s to the early 1980s, narratologists were particularly interested in identifying and defining narrative universals" (Meister, n.d., cited in Hune et al, 2009, p. 329). This tendency was in air even a decade later in 1993 which is evident in a definition f $\mathrm{m}$ rratology from those years: "the set of gen 1 sta ements on narrative genres, on the systo atic of n rratng (telling a story) and on the structur of $\mathrm{plo}$ (Rya

von Alpher, 1993, p. 110). However, a decade later, narratolosy was lternati ${ }^{1} \mathrm{v}$ described as (a) a theory (Prin 2003, 1), b) a method (Kindt and Müller, 2003, „ 21, p, or (c) a discipline (Fludernik and Margolin, 004. 149). However, in Scheffel et al's (n.d.) view sint, the third option seems more suitable since it sub sumes the two previous terms, that is theory and method. They explicate that the term discipline covers both theoretical and practical approaches to narrative and narratology.

A second phase in narratological studies is the post-classical phase. Narratology is not limited to only one theory and discipline. From postclassical perspectives, narratology is a discipline which is wide enough in scope to be applied to other disciplines. As quoted from Rimmon-Kenan (2004), the transition to post-classical narratology is a "shift from a fairly unified discipline to one characterized by a diversity of approaches" ( $p$. 47). This phase is the time for the emergence of inter-disciplinary approaches like 'feminist narratology', 'cognitive narratology', 'post-modern narratology', and other sub-disciplines (ibid., p. 49). Thus, there appears to be two viewpoints toward the concept of narratology. In one, we are faced with the "formalist-structuralist discipline" as it is called by Rimmon-Kenan (2004, p. 44), and in the second, some inter-disciplinary narratology emerges which opens the ground for more practical and in-depth studies.

\section{Components and elements of narratology}

In narratology, a narrative is analyzed from the point of view of its constituent components. In this section, we may point to Jahn's (2005) classification of these components. Jahn suggests three broad categories. The first of these, is narration (voice), focolization (mood), and narrative situation, the second is Action, story analysis, tellability, and the third broad category is about Tense, Time, and Narrative Modes. As one can see, each of these categories carry some subcomponents. For a general understanding, as well as, familiarity with narratological components and elements, some issues about each one of these subcomponents will be raised and explained.

\section{Narration (voice), focolization (mood), and narrative situation}

Aiming to elucidate the concept of narration, some point should be mentioned about narrator since it is a dependent highly related concept. Narrators may be overt or covert. An overt narrator is one who refers to him/herself in the first person ("I", "we" etc.), one who directly or indirectly addresses the narratee, one who offers reader-friendly exposition whenever it is needed. A covert narrator, in contrast, is "one who has a more or less neutral (nondistinctive) voice and style, one who is sexually indeterminate, ..., one wh doe not intrude or interfere, one who lets th story lvents unfold in their natural sequence and tempo" Jo'n, 2005, N3.1.4.). Narrators may uc homo legetic, ytodiegetic, heterodiegetic. This ch fication is ba ed on the narrator's relationship to the st ry Genet , 1980, p. 248, in Jahn, 2005, N3.1.5.). A boms dieget c narrator is present as a character in the story. ahn explains that the prefix 'homo-' suggew that the narrator is within the level of action. There is another term in relation to homodiegetic narrator, which is autodiegetic narrator and which has the same meaning; but the only difference is that the narrator here, is the protagonist. But in a heterodiegetic narration, the story is told by a heterodiegetic narrator who is not present as a character in the story (Jahn, 2005, N3.1.5.).

The second subcomponent is focolization or mood which poses the question of "who sees?" vs. the question of "who speaks" (which is about narrators discussed earlier). Focolization centers on the idea that a specific narration or story is seen/told from whose perspective. In this respect, two terms are introduced: external focolization and internal focolization. External focolization refers to "the candidate for a text's perspectival orientation who is the narrator" 
(Jahn, 2005, N3.2.4.). Internal focolization is when the narrative events are "presented from a character's point of view" (ibid.). Also, four types of focolization are determined by Jahn: fixed focalization, which is the presentation of narrative facts and events from the constant point of view of a single focalizer; variable focalization, that is "the presentation of different episodes of the story as seen through the eyes of several focalizers"; multiple focalization which refers to a technique of "presenting an episode repeatedly, each time seen through the eyes of a different (internal) focalizer"; and finally, collective focalization that is "focalization through either plural narrators (we narrative) or a group of characters (collective reflectors )" (Jahn, 2005, N3.2.4.).

The third subcomponent is narrative situation. In clarifying narrative situation, Jahn mentions Stanzel's model as a base for his discussion. Stanzel has a complex framework about narrative situations $\mathrm{y}$ (11C aims to give some typical patterns of n ativ feares, including features of "relation hip ( nvolv ment distance, pragmatics, knowledge, re jabi, ty: volce, and focalization" (Jahn, 2005, N3.J. V. Accordin, to Jahn (2005), both Genette (1988 [1,83]: ch . 17) an Stanzel (1984), use the term narratim situatio to re er to more complex arrangements or patte ns 1 harrative features. Based on the same source, Genet hires the classifications of voice (narration, ana mood (focolization) so that he can come to some possible combinations of these two. Stanzel is more interested in "describing 'ideal-typical' or (as we shall say) prototypical configurations and arranging them on a 'typological circle' " (1984: xvi, in Jahn, 2005, N3.3.). Concepts like firstperson narrative, authorial narrative, and figural narrative are raised in the discussion of narrative situation which are related to voice. Moreover, we-narratives, you-narratives, simultaneous narration and camera-eye narration are further debates within the narrative situation. All in all, in the narrative situation the aim is to mix some other components in order to achieve a number of new interpretations.

\section{Action, story analysis, tellability}

The second category is action, story analysis, tellability. Action refers to"a sequence of acts and events; the sum of events constituting a 'story line' on a narrative's level of action" (Jahn, 2005, N4.1.). Action refers to a kind of "causal connectivity" between story units (ibid., N4.6.). The other term, tellability is what Abbot (2009) asserts that 'tellability' is originally introduced by Labov (1972). Abbot continues: this is what Prin- ce (2008) has referred to as narratibility, which is what makes a story worth telling. It allows a positive answer to the question "What's the point?"

\section{Tense, time, and narrative modes}

The last of these categories introduced by Jahn (2005), is "Tense, Time, and Narrative Mode". Jahn distinguishes between two kinds of tenses: the narrative past and the narrative present. The use of tense in a character's discourse, Jahn clarifies, depends on some factors like the current point in time in the story's action (Jahn, 2005, N5.1.) However, the tense of a specific narrative does not remain the same in the whole narrative, but it changes. This is where we need the term tense switch/tense shift which refers to a shift from the current narrative tense to the complementary narrative tense (i.e., narrative past to narrative present and vice versa) (ibid.). Jahn also has classified tense according to the anteriority or posteriority relationship between discourse-NOW and story-NOW, which in turn gives up three classifications: retrospective narration which produces a past-tense narrative whose events and action units have all happened in the past; concurrent narration that produces a present-tense narrative whose action takes place at the same time as it is recounted (discourse-NOW and story-NOW are identical); and at last prospec ve m rration produces a future-tense narrative which ecounts events that have not yet occurre (Jahn, 2005 N 1.4.).

Time a ld time analyses are concerned with three estions: Wher?', 'How long?', and 'How often?' Order cef's to th andling of the chronology of the story; ura on ce vers the proportioning of story time and discoy se time; and frequency refers to possible mo of presenting single or repetitive action units (Genette, 1980, pp. 33-85 \& 87-112 \& 113-160; Rimmon-Kenan, 1983, pp. 43-58). The relevant terms one may face in regard to order, are the two basic concepts of flashback/retrospection/analepsis and flashforward/ anticipation/prolepsis. The former is the presentation of events that have occurred before the current story-NOW, while the latter refers to the presentation of a future event before its proper time (Jahn, 2005, N5.2.1.). For determining the duration within a narrative, two fundamental points are necessary: discourse time (the time it takes an average reader to read a story), and story time (the fictional time taken up by an action episode, or, more globally, by the whole action) (ibid., N5.2.2.). Duration, Jahn (2005) affirms, consists of five forms according to the pace of discourse time in relation to story time: isochro- 
nic (or scene based on Genette, 1982), speed-up/ acceleration/ summary, slow-down/ deceleration, ellipsis/ cut/ omission, and pause; Jahn explains these terms mainly referring to Genette (1982), Rimmon-Kenan (1983), and Toolan (1988). Speed-up is when an episode's discourse time is considerably shorter than its story time. Slow-down occurs when an episode's discourse time is considerably longer than its story time. Ellipsis is the stretch of story time which is not textually represented at all; some crititcs, e.g. Genette (1982), Rimmon-Kenan (1983), and Toolan (1988) observe ellipsis as a kind of speed-up (Jahn, 2005, N5.2.3.). Finally, pause is when discourse time elapses on description or comment, while story time stops and no action actually takes place. The third main concept in time is the notion of frequency. Frequency answers the question: 'How often?'. Frequency let's a narrator to hire strategies for recounting events in a summative or repet Ave way. Based on Jahn (2005) there are three or in fr quential modes: a) Singulative telling in whic h the arrawr recounts once what happened ond: b) Re e titive alling, recounting several times wha happened cico c) Iterative telling, recounting once what appene times (ibid., N5.2.4.).

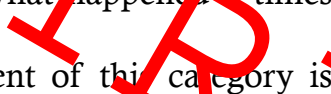
narrative modes. It refers to the ways that nar ative representation can be presented. Jahn a gkes a distinction between telling and showing or tha traditional terms mimesis and diegesis, respectively. He asserts showing is when the reader directly involves in experiencing or witnessing the events of a specific narrative mode. Logically in such a situation there remains little or no room for narratorial mediation (narrative discourse); In telling, the narrator has an overt control of the presentation of actions. Jahn (2005) draws a combinatory conclusive debate from what has been just elaborated. He believes that for each frequential durational relationship (discussed above), there exists a form of narrative mode that is showing or telling. Jahn details such relations and links that in scenic presentation (a durational component), there is a showing mode which presents a continuous stream of detailed action events; in such a case, the durational aspect is isochronious (the story time and discourse time are almost the same) (N5.2.3.). He continues that in summary, there is a telling mode in which the narrator briefly tells readers about a sequence of events, and the durational aspect, is logically, speed-up. In description, Jahn says, where the durational aspect is pause, a sort of telling mode is evident in which the narrator introduces a character or describes the setting. In commentary there exists a telling mode, in which the narrator comments on the instances of the story like characters, actions, etc., thus the durational aspect evident is again pause (Jahn, 2005).

\section{NARRATIVE}

\section{Narrative definition}

An indispensable notion in narratological studies is the narrative. Narrative in its broad sense may refer to a variety of genres. According to Barthes (1977), "the narratives of the world are numberless" (p.20). The essence of this sentence is reflected in the writings of other figures, as well. Fludernik (2006), for instance, believes that "narrative is all around us" (p. 1). But when we speak about narrative, we inevitably think of a 'literary' form, short story or novel. Fludernik writes, narrative is related to the verb 'narrate' and that narrative is not just confined to novels or historical writings (ibid., p. 1). She further broadens the scope of narrative to 'narration' and declares whatever is narrated is a narrative:

Narrative is associated above all with the act of narration and is to be found wherever someone tells us about something: a newsreader on the radio, a teacher at school, a school friend in the playground, a fellow passenger on a train, a ney s-age $t$ t, one's partner over the evening meal, a elevision r porter, a newspaper columnist or th narrator in the envel that we enjoy reading before going to $b$ d. We a -11 narrators in our daily lives, in our onversat ons w th others, and some-

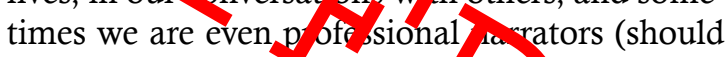
we happen to be, say, te che s, pre s officers or comedians). (Fludernik, 200 o, p. 1

Nash (1994) holds a strmiar perspective toward narratives and says that narratives in one form or another "permeate virtually all aspects of our society and social experience". He expands narrative scope and takes it out from the context of literature and expresses narrative can be found also in "the recollection of life events, in historical documents and textbooks, in scientific explanations of data, in political speeches, and in day-to-day conversation" (p. xi).

In the above definitions, a sort of ubiquitous nature is devoted to narratives, i.e. they are considered to cover a broad range of modes of expressions. Against these definitions which allocate a wide scope to narratives, Abbott explains that other narratologists (Genette,1980; Prince, 1987; Chatman, 1978) define narrative in a limited sense as a kind of storytelling in which a narrator addresses a narratee, or as the telling of 
some past events (Abbott, 2002). As it is evident in this definition, a condition is assumed for a work to be considered narrative, and that is the occurrence of the speech act of telling a story by an agent called a narrator. Furthermore, this definition stresses the telling of a story by a narrator which emphasizes a language-based phenomenon, excluding visual or musical narrative forms.

Narrative has been moreover defined by Toolan (2001) in this way: "narrative is a perceived sequence of non-randomly connected events, typically involving, as the experiencing agonist, humans or quasi-humans, or other sentient beings, from whose experience we human can learn" (p. 2). It seems that for Toolan the feature of "event sequence" is a necessary feature of a narrative.

\section{Narrative features (narrativity)}

There are some major characteristics for narratives it trou uced and discussed by Toolan (2001). He crola ns that narratives have as their features.

a degree of atificjal brication or constructedness

a degree of prefabrication

"trajectory" meaning that th have a begin hing middle, and an end

a "teller" (even if he is invisible)

the feature of "displacement" (the ability o human languages to be able to refer to things ow events that are removed, in space or time, either from the speaker or the addressee)

narratives involve the "recall" of happenings (Toolan, 2001, pp. 4-5).

For other features of narratives we may hint at Sternberg who conceives sequentiality to be a substantial feature. For him sequentiality is the "the play of suspense/ curiosity/surprise between represented and communicative time" (2010, p. 637). These plays of time which create feelings of suspence, curiosity, and surprise, are the building blocks of narratives because non-narratives are deprived of such temporalities. This is more touchable in descriptive or expository texts which are deprived of this feature. When we read such texts, we merely get some information about something and we are not involved in it. Narratives on the other hand, make readers involved by such plays of time which in turn arise their curiosity and the features Sternberg mentioned. Another feature, is the causal connections between the events in a narrative. The literature is rife with this notion that this sense of causal agency can account for "a necessary condition of narrativity” (Richardson, 1997, p. 106; White, 1981; Bal,
1997; Bordwell, 1985; Rabinowitz, 1987).

Narrativity is what Schmid also considers. Schmid (2010) develops his theory of eventfulness. He defines event as "a special occurrence, not part of everyday routine, unprecedented incident, deviation from a normative regularity, meaningful departure from the norm, crossing of a prohibition border" (p. 8). Based on Schmid the conditions by which eventfulness is achieved, are: "relevance, unpredictability, persistence, irreversibility, and non-iterativity" (pp. 8-12).

\section{Narrative genres}

Narrative is not limited to one scope and type, but it is wide and encompasses many genres. Jahn quotes Roland Barthes' list in which he mentions some of these genres: There are countless forms of narrative in the world. First of all, there is a prodigious variety of genres, each of which branches out into a variety of media, as if all substances could be relied upon to accommodate man's stories. Among the vehicles of narrative are articulated language, whether oral or written, pictures, still or moving, gestures, and an ordered mixture of all those substances: narrative is present in myth, legend, fables, tales, short stories, epic history, tragedy, drame [suspense drama], comedy, pantomime, paintings (in Santa Ursula by Carpaccio, for instance), stainedgla - win lows, movies, local news, conversation. $\mathrm{M}$ oreover, in this infinite variety of forms, it is pr sent at all tir co in all places, in all societies; indeeu narrati e starts with the very history of mankind; the is not here as never been anywhere, any people wit hou narrat $m$ all classes, all human groups, have hein sto es, al d very often those stories are enjoyed by hen of different and even opposite cultural backgromus *...+. (Barthes, 1975 , p. 237; Jahn's emphases, Cited in Jahn, 2005, N2.2.1.

\section{CONCLUSION}

Narratology as a vast branch of study entails the analysis of structures that reside in a narrative. What was already discussed in this article may give readers a general picture of the narratological world. As it was explicated, narratology deals with narratives' traits which ultimately distinguish them from other genres. The two basic ever present terms in this fields were realized to be story and discourse which refer to modes of presentation and the meaning/content, respectively. What was emphasized in this investigation (specifically sections 3 ), was the layers by which a narrative may be inspected. The surface layer 
of a narrative was the arena on which classical narratologists could function. On this layer, they suffice to explain the basic observable features of language in a specific narrative. They did not go beyond the level of the narrative itself (words, sentences, or the whole written material). Nevertheless, the newer approaches in the study and analysis of a narrative, benefit from other disciplines. This hybrid approach for narrative analysis has a wider scope and thus goes beyond textual levels. This kind of approach may include issues about feminism, cognitivism, post-modernism, etc. Three sections were devoted to the elements of which narratology is made up. These elements (narration, focolization, narrative situation, action, story, analysis, tellability, tense, time, and narrative modes), can be viewed and analyzed from a narratological perspective in a specific narrative text. What usually is done in the analysis of these elements is to determine how a particular element is shoy $\mathrm{n} \mathrm{M}$ a narrative or how much it is similar/diffent w th the discourse. This study, fo used on the consept of narrative, too. Narratology is vita iy lepend on narrative as it has a determinn role in this 1er. This study was a struggle to coven the mo st crucio and key concepts relating to narrativ as well. (he d finition of narrative was put forward ir thi review. Furthermore, the features which made a pie e of writing a narrative were scrutinized. To etter digest what a narrative is, this article immersed more deeply in narrative and studied its elements and genres. This was done to give readers a more comprehensive idea of narratives.

\section{REFERENCES}

Abbot, H.P. (2009). Narrativity. In Hühn, P., Meister, J.C., Pier, J., Schmid, W., Schönert, J. (Eds.). Handbook of Narratology. Berlin: Walter de Gruyter.

Abbott, H.P., (2002). The Cambridge Introduction to Narrative. Cambridge, UK: Cambridge University Press.

Bal, M., (1991). Narration and focalization. In Bal, M. (Ed.).(2004). Narrative Theory, London: Routledge. 1, 263-296.

Bal, M., 1997. Narratology: Introduction to the Theory of Narrative (2nd ed.). Toronto: University of Toronto Press.

Barthes, R. (1977). Introduction to the structural analysis of narratives. In Mcquillan, M. (Ed.). (2000). The Narrative Reader. London: Routledge. 109-114.

Bordwell, D. (1985). Narration in the fiction film. Madison: U of Wisconsin P.

Chatman, S. (1978). Story and Discourse: Narrative Structure in Fiction and Film. Ithaca and London: Cornell University Press.

Prince, G. (2003). A Dictionary of Narratology. Lincoln: $\mathrm{U}$ of Nebraska P.

Toolan, M. (2001). Narrative: A Critical Linguistic In-

troduction. London: Routledge.

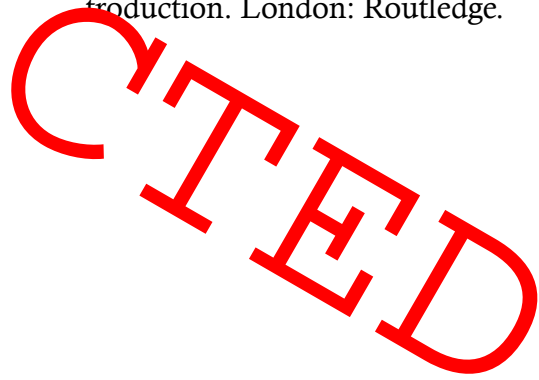

